\title{
Effect of Seasons and Sources of Raw Water on the Properties of Water Treatment Residue Compacted Clay
}

\author{
Woottipong Prakongwittaya, Suwimol Asavapisit, Rungroj Piyapanuwat, and Teerawut Muhummud
}

\begin{abstract}
Seasons affect the rainfall and river current. Thus, the quality of raw water from rivers as well as the property of water treatment residue (WTR) from water treatment plant are season-dependent. In this research, the season-dependent properties of WTR as compacted clay from five treatment plants located in the central of Thailand has been studied. These properties included Liquid Limit (LL), Plastic Limit (PL), Shrinkage Limit (SL), particles size, Optimum Moisture Content (OMC), and Unconfined Compressive Strength (UCS). It is found that the seasons and the sources of raw water in Thailand slightly affected the properties of WTR. The highest quality WTR was obtained from Tha Chin River, especially, those collected at the end of winter. A comparison between clay and WTR properties showed that their physical properties were similar. However, their strength and permeability were different. Clay-WTR mixture with the ratio of $1: 1$ is recommended for landfill liner because it offers comparable properties with clay but with a lower material cost.
\end{abstract}

Index Terms-Atterberg's limit, compaction test, permeability, unconfined compressive strength, water treatment residue.

\section{INTRODUCTION}

Water treatment residue (WTR) is waste from the production of public water supply. These residuals may be organic and inorganic compounds depending on the source of raw water and the type of treatment processes. Conventionally, WTR has been disposed by landfilling, hence, more landfill sites are required every year. Table I shows the relationship between water supply production and WTR from water treatment plants in Thailand. In Year 2015, the production of public water supply in the whole country produced WTR in the amount of 137,090 ton and it is causing more negative impact on the environment every year. WTR has its properties similar to clay but has been rarely used as clay replacement due to its little known properties.

Several researches have been conducted to obtain more insight information on WTR properties and to improve its properties for current and future utilization [1]-[3], including cement production [4], [5] and clay replacement as a cheaper

Manuscript received October 25, 2016; revised December 28, 2016 Woottipong Prakongwittaya and Suwimol Asavapisit are with Environmental Technology, School of Energy, Environment and Materials, KMUTT, Bangkok, Thailand (e-mail: woottipong.pra@kmutt.ac.th, suwimol.asa@kmutt.ac.th).

Rungroj Piyapanuwat is with King Mongkut's University of Technology Thonburi (Ratchaburi), Ratchaburi, Thailand (e-mail: rungroj.piy@kmutt.ac.th).

Teerawut Muhummud is with Department of Civil Technology Education, School of Industrial Education and Technology, KMUTT Bangkok, Thailand (e-mail: teerawut.muh@kmutt.ac.th). material [6], [7]

TABLE I: OPERATION OF WATER TREATMENT PLANT IN 2015

\begin{tabular}{|c|c|c|}
\hline Water Treatment Plants & Water Production, $\mathrm{m}^{3}$ & WTR, ton \\
\hline \multicolumn{3}{|l|}{ Metropolitan Waterworks } \\
\hline \multicolumn{3}{|l|}{ Authority } \\
\hline - Bangken & $1,352,632,320$ & 55,469 \\
\hline - Samsen & $292,000,000$ & 10,220 \\
\hline - Thonburi & $62,050,000$ & 2,172 \\
\hline - Mahasawat & $255,500,000$ & 8,943 \\
\hline Total & $1,962,182,320$ & 76,804 \\
\hline \multicolumn{3}{|l|}{$\begin{array}{l}\text { Provincial Waterworks } \\
\text { Authority }\end{array}$} \\
\hline - Bang Len & $135,050,000$ & 4,727 \\
\hline - Other 234 branches & $1,587,424,073$ & 55,559 \\
\hline Total & $1,722,474,073$ & 60,286 \\
\hline Grand Total & $3,684,656,393$ & 137,090 \\
\hline
\end{tabular}

The quality of raw water for water supply systems depends on the suspended sediments. During rainy season, storms deliver large amounts of water to a river and bring along lots of eroded soil from the earth surface. Rivers carry more sediments during rainy season than other time of the year. The amount and property of water treatment residue (WTR) from water treatment plant, thus, are season-dependent.

To provide database for material application, the variation of WTR properties due to season change during the year was investigated using data obtained from water treatment plants receiving raw water from different sources, i.e., rivers. Furthermore, the WTR properties were compared to those of clay to evaluate the possibility of clay replacement utilization.

\section{LABORATORY INVESTIGATION}

\section{A. Materials}

Water Treatment Residue (WTR) samples from four water treatment plants in Bangkok (Bang Khen, Samsen, Thonburi, and Mahasawat Plants) and one in nearby province (Bang Len Plant in Nakhon Pathom Province) were collected and studied for their season-dependent properties. Bang Khen, Samsen, Thonburi Plants use water from Chao Phraya River while Bang Len and Mahasawat Plants use water from Tha Chin River and Mae Klong River, respectively, to produce piped water for their respective regions. WTR samples were collected at four different times of the year, which were November 2014, February 2015, May 2015, and August 2015. When they were dry, they were grounded by Los Angeles Abrasion machine to reduce their particle sizes, then passed through sieve No. 40, and stored in containers until testing.

Clay sample collected at the depth of 6-8 meter from the construction site of KLK PRODUCTS COMPANY LIMITED in Chachoengsao Province, Thailand, was used to 
compare its properties with those of WTR from various sources.

\section{B. Laboratory Test}

The following properties of WTR collected from different plants were investigated and compared with those of clay:

- distribution of particle sizes was studied using hydrometer following ASTM D422-63(2007)e2 [8],

- physical properties including Liquid Limit (LL), Plastic Limit (PL) and Shrinkage Limit (SL) were tested in accordance with ASTM D4318-10 [9],

- dry density was determined in accordance with ASTM D 854-02 [10],

- chemical compositions were determined by X-ray fluorescence (XRF), and

- mechanical properties was obtained from an unconfined compression test in accordance with ASTM D2166-00 [11]. The water content for each specimen was found from Optimum Moisture Content (OMC) using modified Proctor compaction test in accordance with ASTM D1557-02 [12]. Compacted WTR specimens were prepared in cylindrical mold with the dimension of $5 \mathrm{~cm}$ in diameter and $10 \mathrm{~cm}$ in height (the specimens size was smaller than standard one but the same modified Proctor compaction energy was applied.)

\section{RESULTS AND DISCUSSION}

\section{A. Particle Size Distribution}

The distribution of particle sizes (as sand, silt, and clay) of WTR from five different water treatment plants was shown in Fig. 1.

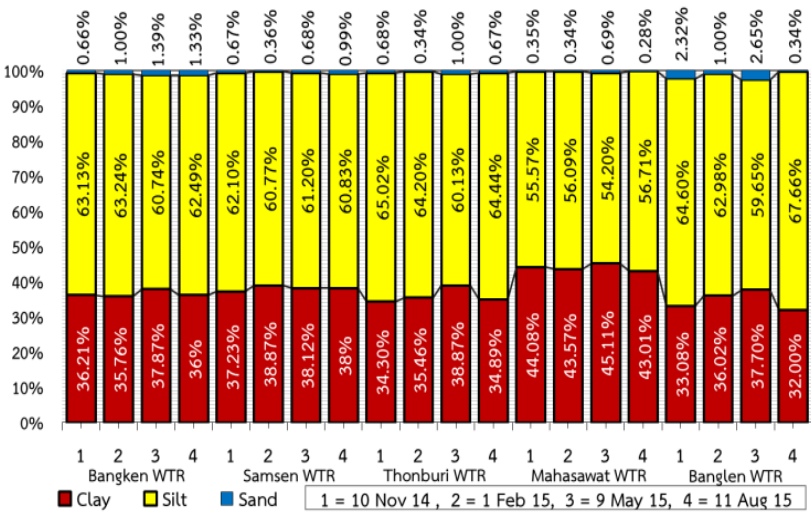

Fig. 1. Distribution of WTR particle sizes.

It can be seen that the particle size distributions of WTR from these plants were similar except for WTR from Mahasawat Plant. Sand, silt, and clay contents of WTR from Bang Khen, Samsen, Thonburi, and Bang Len Plants were in the range of $0.3-2.7 \%, 59.7-67.7 \%$ and $32.0-38.9 \%$, respectively, while those of WTR from Mahasawat Plant were in the range of $0.3-0.7 \%, 54.2-56.7 \%$ and $43.0-45.1 \%$, respectively. This is because Tha Chin River is a branch of Chao Phraya River and both of them mainly run through alluvial plains, thus, they have similarity in sediment particle sizes. Meanwhile, Mae Klong River mainly runs through mountain areas, thus, it contains sediments with larger particles which are likely to sink into the river bed quicker and allow smaller particles to reach the water treatment plants.

\section{B. Physical Properties}

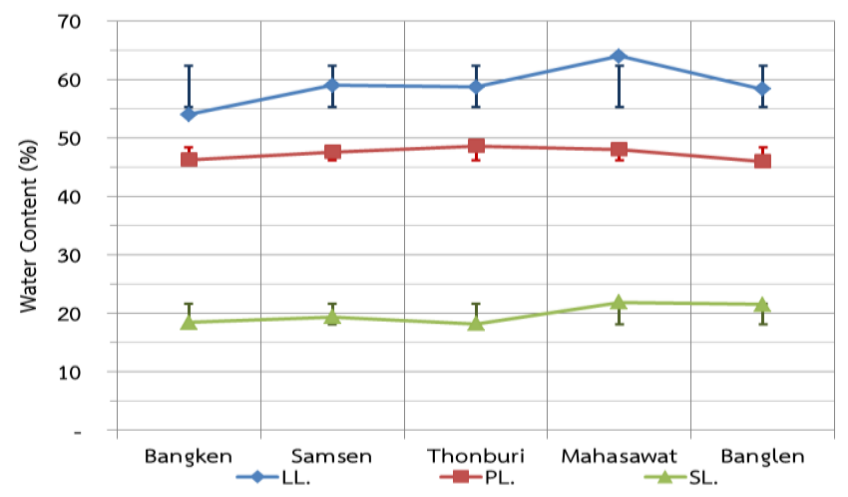

Fig. 2. Atterberg's Limits of WTR

The average water contents at Liquid Limit (LL), Plastic Limit (PL), and Shrinkage Limit (SL) of WTR collected from different time of the year were shown in Fig. 2. It is seen that water contents at PL and SL were similar for all five plants as they ranged from $46.0 \%$ to $48.6 \%$ and $18.2 \%$ to $21.5 \%$, respectively. Whereas, those water contents at LL were slightly different. The water contents at LL of WTR from Samsen, Thonburi, and Bang Len Plants ranged from 58.3\% to $59.0 \%$. The lowest and highest water contents at LL of $54.0 \%$ and $64.0 \%$ were found in WTR from Bang Khen and Mahasawat Plants, respectively. This is because WTR from Mahasawat Plant contained the highest clay content compared to the other plants.

\section{Mechanical Property}

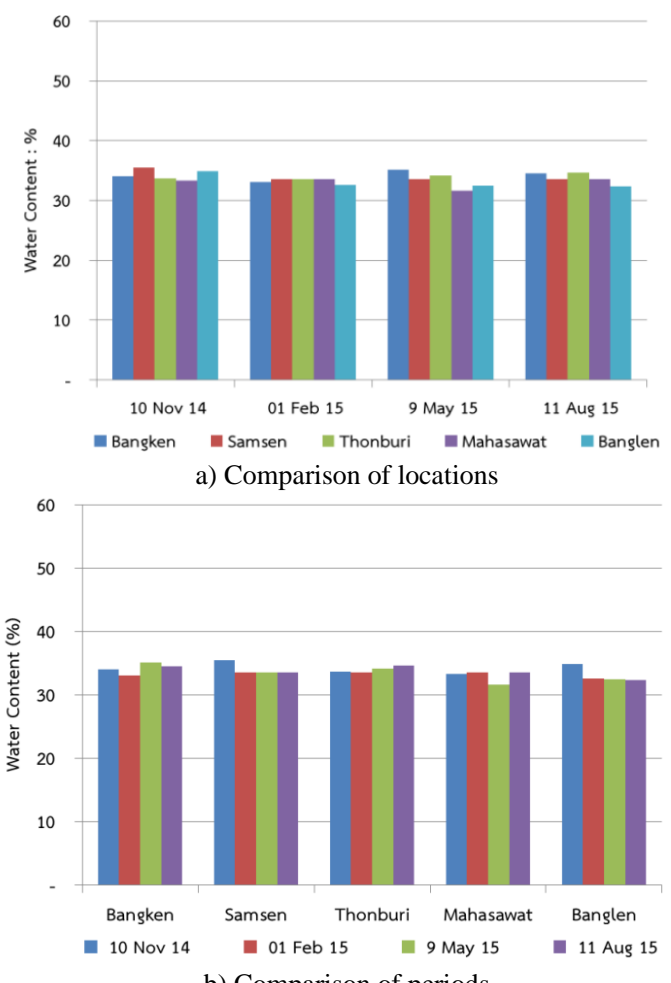

b) Comparison of periods

Fig. 3. Optimum water content of WTR.

The OMCs used for Unconfined Compression Test of 
WTR specimens were shown in Fig. 3. They were obtained from modified Proctor compaction test. Fig. 3 indicates that the collecting periods and locations did not significantly affect the OMC as each plant had its OMC mean and standard deviation values of WTR collected from different periods ranging from $33.0 \%$ to $34.2 \%$, and $0.5 \%$ to $1.2 \%$, respectively. The minimum of OMC was found in Bang Len Plant because of high sand contents. As WTR particle size increased, OMC reduced.

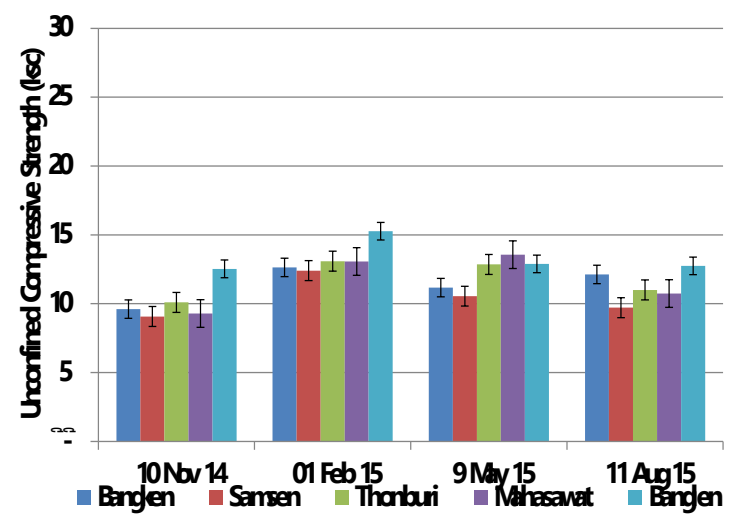

a) Comparison of locations

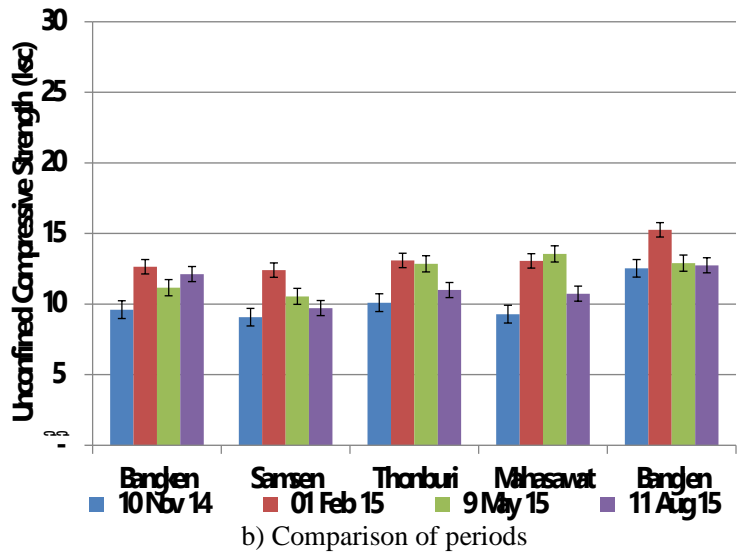

Fig. 4. Unconfined compressive strength of compacted WTR.

Fig. 4 shows Unconfined Compressive Strength (UCS) of the compacted WTR specimens. It can be seen that the UCS of WTR were slightly affected by collecting periods and locations. Fig. 4a indicates that WTR collected from Bang Len Plant had the highest strength, while that collected from Samsen Plant had the lowest strength. The UCS of WTR from Bang Len Plant (12.53, 15.27, 12.90, and 12.75 ksc for WTR collected in November 2014, February 2015, May 2015, and August 2015, respectively) was higher than other plants by $20 \%$.

Moreover, it is found from Fig. 4b that WTR collected at the end of winter (February 2015) had the highest strength while those collected at the end of the rainy season (November 2014) had the lowest strength. This is because WTR collected at the end of the rainy season and early winter was contaminated by rain and storms.

\section{Possibility of Substitution Clay Using WTR}

The experimental test results presented in Sections A, B, and $\mathrm{C}$ showed that WTR collected from Bang Len Plant had the highest strength. As a result, its properties from sample collected in February 2015 were used to compare with those of clay sample collected from the construction site in
Chachoengsao Province, Thailand.

A comparison of their chemical composition was shown in Table II.

TABLE II: CHEMICAL COMPOSITION CLAY AND WTR

\begin{tabular}{lll}
\hline \hline Chemical Composition & Clay & WTR \\
\hline $\mathrm{SiO}_{2}$ & 61.52 & 59.59 \\
$\mathrm{Al}_{2} \mathrm{O}_{3}$ & 20.51 & 26.51 \\
$\mathrm{CaO}$ & 1.20 & 1.29 \\
$\mathrm{Fe}_{2} \mathrm{O}_{3}$ & 9.18 & 7.36 \\
$\mathrm{SO}_{3}$ & 3.78 & 0.79 \\
$\mathrm{MgO}$ & 2.33 & 1.12 \\
$\mathrm{Na}_{2} \mathrm{O}$ & 0.91 & 0.34 \\
\hline \hline
\end{tabular}

It is seen from Table II that clay and WTR have similar $\mathrm{SiO}_{2}$ and $\mathrm{Al}_{2} \mathrm{O}_{3}$ contents. $\mathrm{SiO}_{2}$ contents in clay and WTR were $61.52 \%$ and $59.59 \%$, respectively. Whereas, $\mathrm{Al}_{2} \mathrm{O}_{3}$ contents were $20.51 \%$ and $26.51 \%$, respectively.

Comparisons of their particle sizes distribution, and engineering properties were shown in Fig. 5, and Table III, respectively.

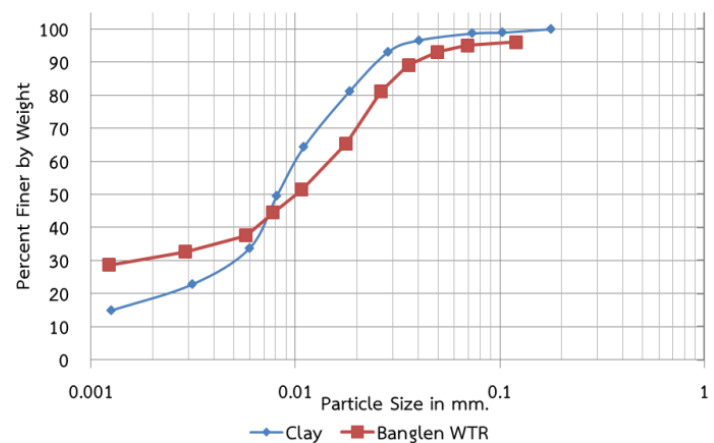

Fig. 5. Percentage of particle sizes of clay and WTR from bang len plant.

TABLE III: ENGINEERING PROPERTY OF CLAY AND WTR

\begin{tabular}{ccc}
\hline \hline Particle size contents & Clay & WTR \\
\hline Sand (\%) & 1.68 & 1.58 \\
Silt (\%) & 78.63 & 63.72 \\
Clay (\%) & 19.69 & 34.70 \\
\hline Physical Properties & & \\
\hline LL (\%) & 65.40 & 58.29 \\
PL (\%) & 58.33 & 45.97 \\
SL (\%) & 41.20 & 21.50 \\
\hline \hline
\end{tabular}

Fig. 5 and Table III indicate that the properties WTR and clay from selected sites were also similar. There was no significant difference in their particle size as their sand, silt, and clay contents were $1.68 \%, 78.6 \%$, and $19.7 \%$ for clay sample and $1.58 \%, 63.7 \%$, and $34.7 \%$ for WTR sample. In addition, it was found that the water content at SL of WTR was lower by half. It indicated that the shrinkage of WTR was lower than clay.

Based on their similar properties, WTR seems to be a possible alternative to be clay substitute since it offers a lower material cost for construction. To ensure WTR application as clay replacement, further investigation was conducted on their dry density, OMC, unconfined compressive strength (UCS), and permeability. The test results (discussed later) indicated that WTR had a lower strength and a higher permeability and its permeability coefficient almost exceeded the value specified in landfill liner standard. As a result, a clay-WTR mixture (CWTR) with the ratio of WTR to clay 1:1 was also added in this study and its properties were compared to those of clay and WTR and discussed. 
The relationship between dry density and moisture content of clay, WTR, and clay-WTR mixture (CWTR) is shown in Fig. 6. Their dry density, OMC, UCS, and permeability coefficient were shown in Table IV.

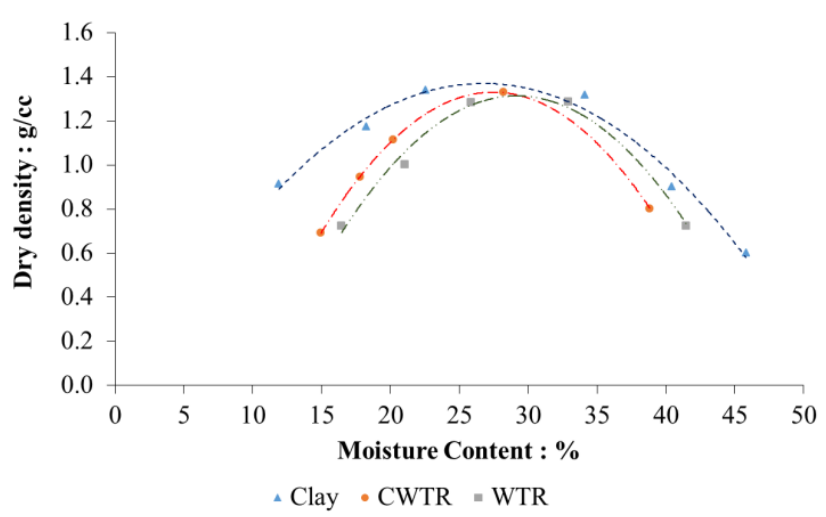

Fig. 6. Dry density and moisture content relationship.

TABLE IV: UNCONFINED COMPRESSIVE STRENGTH OF COMPACTED CLAY AND WTR FROM BANG LEN PLANT

\begin{tabular}{lllll}
\hline \hline Sample & $\begin{array}{l}\text { Dry } \\
\text { Density } \\
\left(\mathrm{g} . / \mathrm{cm}^{3}\right)\end{array}$ & $\begin{array}{l}\text { Optimum } \\
\text { Water } \\
\text { Content }(\%)\end{array}$ & $\begin{array}{l}\text { Unconfined } \\
\text { Compressive } \\
\text { Strength } \\
(\mathrm{ksc})\end{array}$ & $\begin{array}{l}\text { Permeability } \\
\text { Coefficient } \\
(\mathrm{cm} / \mathrm{s})\end{array}$ \\
\hline Clay & 1.35 & 26.95 & 17.58 & $3.647 \times 10^{-8}$ \\
CWTR & 1.34 & 28.20 & 15.27 & $7.343 \times 10^{-8}$ \\
WTR & 1.32 & 28.86 & 13.36 & $9.878 \times 10^{-8}$ \\
\hline \hline
\end{tabular}

The property comparisons of clay, CWTR, and WTR in Table IV indicated that

- their dry densities almost identical,

- OMC of CWTR and WTR were 5\% and 7\%, respectively, larger than that of clay,

- strength of WTR was $24 \%$ lower than that of clay,

- permeability coefficients of WTR was just slightly below the standard requirement for landfill liner $\left(1 \times 10^{-7} \mathrm{~cm} / \mathrm{s}\right)$,

- by mixing WTR with clay, a $14 \%$ increase in strength and $26 \%$ decrease in permeability were observed.

It can be concluded that WTR should not be fully used to replace clay since there are some properties that are much different. Based on observation found in this study, the clay-WTR mixture is recommended to be utilized as clay replacement material in some construction application such as compacted clay liner, subbase, etc., since it offers almost the same properties with a lower material cost.

\section{CONCLUSION}

The experimental results indicated that the physical properties of WTR, namely liquid limit (LL), plastic limit (PL) and shrinkage limit (SL), from all five plants were similar. However, the content of sand, silt, and clay of WTR received from the plants that treated raw water from different rivers were different. The unconfined compressive strengths (UCS) of WTR were slightly affected by collecting periods and locations. WTR collected from Bang Len Plant at the end of winter (February 2015) was found to have the highest strength and then used for further study to compare its properties with clay from selected site.

Property comparisons between clay and WTR collected from Bang Len Plant showed that their physical properties were comparable. However, UCS and permeability coefficient of clay were much superior that those of WTR. As a result, use of clay-WTR mixture with the ratio of $1: 1$ is recommended for landfill liner because it offers almost the same properties with clay but with a lower material cost.

\section{ACKNOWLEDGMENT}

This research wishes to express the special thanks to the technical staffs at King Mongkut's University of Technology Thonburi for their help during laboratory testing.

\section{REFERENCES}

[1] J. Pirot, "Improvement of compacted clay liner using lime and fly ash," M.S. thesis, Environmental Technology, King Mongkuts University of Technology Thonburi, Bangkok (Thailand), Graduate School, Bangkok, Thailand, 2000.

[2] O. Charlinee, A. Suwimol, and P. Rungroj, "Effect of $\mathrm{SiO}_{2} / \mathrm{Al}_{2} \mathrm{O}_{3}$ and alkalinity types on strength development of geopolymer synthesized from water treatment residue," presented at 17th National Convention on Civil Engineering (Civil Engineering for Integrated Developments), Centara Hotel and Convention Centre Udonthani, Udonthani, Thailand, 9-11 May 2012.

[3] C. Oonsang, S. Asavapisit, and R. Piyaphanuwat, "Effect of $\mathrm{SiO}_{2} / \mathrm{Al}_{2} \mathrm{O}^{3}$ and alkalinity types on strength development of geopolymer synthesized from water treatment residue," presented at 17th National Convention on Civil Engineering (Civil Engineering for Integrated Developments), 9-11 May 2012, Centara Hotel and Concention Centre Udonthani, Udonthani, Thailand.

[4] A. Tananchaya, S. Asavapisit, and R. Piyaphanuwat, "Effect of $\mathrm{SiO}_{2} / \mathrm{Al}_{2} \mathrm{O}^{3}$ on durability of geopolymer synthesized from water treatment residue solidified plating sludge," Int. Conf. on Sustainable Environmental Technology (ICSET), Century Park Hotel, Bangkok, Thailand, 2012, pp. 45-47.

[5] D. Kanungnich, A. Suwimol, and W. Jaruwat, "The sludge from the water plant is used as a raw material for cement production," presented at the National Convention on Civil Engineering No. 14,Thailand, May 13-15, 2009

[6] K. Vijittra, A. Suwimol, and P. Rungroj, "Effect of $\mathrm{SiO}_{2} / \mathrm{Al}_{2} \mathrm{O}_{3}$ on immobilization of plating sludge in geopolymer synthesized from water treatment residue," presented at 17th National Convention on Civil Engineering (Civil Engineering for Integrated Developments), Centara Hotel and Convention Centre Udonthani, Udonthani, Thailand, 9-11 May 2012.

[7] Y. Guney, B. Cetin, A. H. Aydilek, B. F. Tanyu, and S. koparal, "Utili-zation of sepiolite materials as a bottom liner material in Solid waste landfills," Waste Management, vol. 34, no. 2014, pp. 112-124, 2013.

[8] American Society of Testing and Materials, "ASTM D422-63(2007)e2.standard test method for particle-size analysis of soils," Pennsylvania, USA, 2007.

[9] American Society of Testing and Materials, "ASTM D 4318-10. standard test methods for liquid limit, plastic limit, and plasticity index of soils," Pennsylvania, USA, 2010.

[10] American Society of Testing and Materials, "ASTM D 854-02. Standard test methods for specific gravity of soil solids by water pycnometer," Pennsylvania, USA, 2002.

[11] American Society of Testing and Materials,"ASTM D 2166-00. Standard test methods for unconfined compressive strength of cohesive soils," Pennsylvania, USA, 2000.

[12] American Society of Testing and Materials, "ASTM D 1557-12. Standard test methods for laboratory compaction characteristics of soil using modified effort $\left(56,000 \mathrm{ft}-\mathrm{lb} / \mathrm{ft}^{3} \quad\left(2,700 \mathrm{kN}-\mathrm{m} / \mathrm{m}^{3}\right)\right)$,' Pennsylvania, USA, 2002.

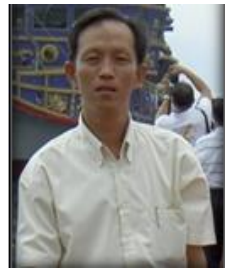

Woottipong Prakongwittaya was born on July 23 1967 in Bangkok, Thailand. He received his bachelor of science $1^{\text {st }}$ class honors in construction industrial technology in 2002 from Kanchanaburi Rajabhat Institute, Thailand, and the master of science in industrial education (civil engineering) in 2009 from King Mongkut's University of Technology Thonburi (KMUTT), Thailand. Now, he is studying his Ph.D. in 
environmental technology at KMUTT, Thailand. His current research interests are in the area of construction material and environmental technology and management.

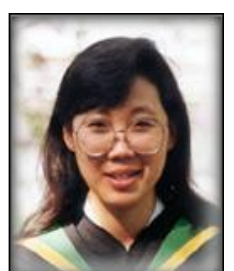

Suwimol Asavapisit was born in Thailand. She received her Ph.D. in environmental engineering in 1998 from University of London, UK. She is an associate professor at School of Energy Environment and Materials, King Mongkut's University of Technology Thonburi (KMUTT), Thailand. Her current research interests are in the area of stabilization/solidification of heavy metal sludge, reuse of non-hazardous industrial wastes in building materials, synthesis of zeolites from alumino-silicious wastes, and controlled release of nutrient from fertilizer coated with polymer.

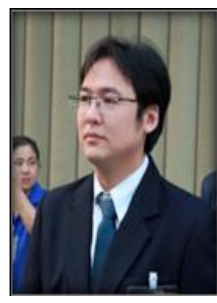

Rungroj Piyaphanuwat was born in December 29, 1980 in Bangkok, Thailand. He received his bachelor of science in civil technology education in 2003, and received his master and Ph.D. in environmental technology in 2006 and 2010, respectively, from KMUTT, Thailand. As part of his Ph.D. program, he had studied and conducted his research at the Department of Chemistry, University of Aberdeeen for 6 months. After his graduation, he has been working as a lecturer at the Department of Civil Technology Education, KMUTT for 2 years, and as an Assistant Professor at the KMUTT (Ratchaburi Campus) since 2014. His current research interests are in the area of cement chemistry, concrete technology, waste utilization, construction material, environmental technology, and hazardous and solid waste management.

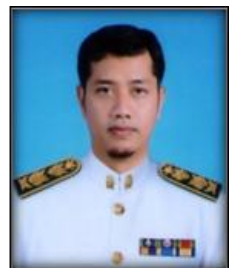

Teerawut Muhummud was born in Thailand. He received his Ph.D. in civil engineering in 2003 from Lehigh University, USA. He is a lecturer at the Department of Civil Technology Education, King Mongkut's University of Technology Thonburi (KMUTT), Thailand. His current research interests are in the area of earthquake engineering, structural steel and composite construction, and construction material. 